\title{
FTIR Study of the Relation, between Extra-framework Aluminum Species and the Adsorbed Molecular Water, and its Effect on the Acidity in ZSM-5 Steamed Zeolite
}

\author{
Luis Fioravanti Isernia* \\ Laboratorio de Tamices Moleculares, Universidad de Oriente - UO, Maturín, Monagas, Venezuela
}

Received: September 21, 2011; Revised: December 30, 2012

\begin{abstract}
The infrared spectroscopy study of zeolite samples, obtained by steam treatment at $560-960{ }^{\circ} \mathrm{C}$ of the ZSM-5 catalyst (framework $\mathrm{Si} / \mathrm{Al}$ ratio of 13), suggests an association between adsorbed molecular water and extra-framework aluminum hydroxyls generated after treatment. Moreover, infrared spectroscopy of adsorbed pyridine shows the reduction of the densities of Brönsted and Lewis sites, when treatment temperature rises, with contradicts the frequently accepted mechanism of the transformation of two bridged $\mathrm{Si}-\mathrm{OH}-\mathrm{Al}$ groups for each Lewis site generated. The gradual conversion of the octahedral extra-framework aluminum (Lewis-associated) in polymeric species with low acidity is the most probable cause of this behavior. On the other hand, the apparent decline of the acid Brönsted strength, with the increase in the temperature of the hydrothermal treatment, has two possible causes: a) the decreasing accessibility, of the pyridine molecular probe to bridged Si-OH-Al groups with the strongest Brönsted acidity, inside the channels, and b) the gradual transformation of these groups into extra framework species of weak acidity.
\end{abstract}

Keywords: hydrothermal dealumination, infrared spectroscopy, ZSM-5 zeolite, Brönsted and Lewis sites

\section{Introduction}

The zeolite-based catalysts, subjected to high temperature water steam regeneration cycles, undergo a partial exit of tetrahedral coordinated aluminum, out of the crystalline network and the gradual decrease of the catalytic activity by reduction of the number of acid sites.

In the presence of excess steam the disappearance of two bridged ( $\mathrm{Si}-\mathrm{OH}-\mathrm{Al})$ sites for each Lewis site generated is frequently reported. Several authors have propused ${ }^{1-5}$ that the interaction between two bridged $\mathrm{Si}-\mathrm{OH}-\mathrm{Al}$ sites, associated ${ }^{6}$ with Brönsted acidity, generate an extra-framework $\mathrm{Al}(\mathrm{OH})^{2+}\left(\right.$ or $\left.\mathrm{AlO}^{+}\right)$, which has been considered ${ }^{7-9}$ as the true carrier of Lewis acidity. It is generally accepted that the extra-framework aluminum (EFAL) generated after hydrothermal treatment is deposited in the form of 4,5 and 6 coordinate monomeric species ${ }^{10,11}$, where 5 and 6 are related with the Lewis acidity in zeolites. On the other hand, the formation of four-coordinate polymeric aluminum species of low acidity on the surface zeolite crystals, has been reported ${ }^{1,12}$.

Zeolite MFI is an interesting shape-selective solid acid catalyst. However, despite their widespread use in a variety of petrochemical processes, information about the catalytic active centers (bridged Si-OH-Al sites) is not completely understood. This pentasil-type zeolite ${ }^{13-15}$, is characterized by a low content of aluminum ( $\mathrm{Si} / \mathrm{Al10}$ ), a medium pore size $(5.1 \times 5.7 \AA)$, great deactivation resistance and high thermal stability.

Fourier transform infrared (FTIR) spectroscopy is widely used in the characterization of catalysts due to its

*e-mail: luis.isernia@gmail.com capacity to provide information without destroying the matrix. On the other hand, the use of special cells ${ }^{16-18}$, allows tracking the changes occurring in the IR bands of basic probes, adsorbed on the catalyst acid sites ${ }^{19-21}$, due to changes in the nature and distribution of these sites. For example, interaction of pyridine with the acid sites of the catalyst, generates a series of signals, among which two are prominent: one signal around $1545 \mathrm{~cm}^{-1}$ (pyridinium ion bonded to a Brönsted site) and another near $1455 \mathrm{~cm}^{-1}$ (pyridine adsorbed on Lewis acid sites).

The values of the extinction coefficients $\in_{\mathrm{B}}$ and $\epsilon_{\mathrm{L}}$, based on the absorbance of these bands, have been reported $^{22,23}$, so that they may be used in the estimation of the concentrations of these sites.

The partial disappearance of the $\mathrm{Si}-\mathrm{OH}-\mathrm{Al}$ groups can be followed by checking for changes in intensity and position of the $\mathrm{O}-\mathrm{H}$ stretching vibrations ${ }^{24}$ in the region located between 3700 and $3500 \mathrm{~cm}^{-1}$. The position and the number of these peaks or bands can vary from one zeolite to another. For example, the bands found at 3640 and $3540 \mathrm{~cm}^{-1}$ due to bridging hydroxyl groups $(\mathrm{Si}-\mathrm{OH}-\mathrm{Al})$ in faujasite, are replaced in mordenite and ZSM- 5 by a single band ${ }^{25}$ between 3600 and $3615 \mathrm{~cm}^{-1}$.

The dealumination of a zeolite by hydrothermal treatment ${ }^{26-28}$ frequently leads to a decrease of its crystallinity, due to the partial collapse of its microporous structure ${ }^{24,29}$ through a mechanism which is not yet fully understood. Fourier transform infrared (FTIR) spectroscopy works complementary to $\mathrm{X}$-ray diffraction ${ }^{7,24,29,30}$ in search for changes in the crystallinity ${ }^{31}$, by comparing the peak 
intensities in the region of 1300 to $300 \mathrm{~cm}^{-1}$. These bands are grouped in two types of vibrations of the tetrahedral $\mathrm{TO}_{4}$ units (where $\mathrm{T}=\mathrm{Al}$ or $\mathrm{Si}$ ):

- Vibrations related to the connections between $\mathrm{TO}_{4}$ tetrahedra, which are therefore sensitive to structural modifications;

- Vibrations into the $\mathrm{TO}_{4}$ tetrahedra, which are insensitive to structural modifications.

For ZSM-5 zeolites ${ }^{24}$, double ring vibration band at $550-560 \mathrm{~cm}^{-1}$ belongs to the type (a), whereas the band at $800 \mathrm{~cm}^{-1}$ of the symmetric stretching mode of internal $\mathrm{TO}_{4}$ tetrahedra belongs to the type (b). Subsequently, the ratios between the absorbances of these bands can be taken as an acceptable criterion of crystallinity.

In this work, Fourier transform infrared (FTIR) spectroscopy is used to study the nature of adsorbed molecular water, the segregation of aluminum outside the crystal framework, its inter-conversion between forms with different numbers of coordination, and their influence on the acidity of a ZSM-5 zeolite placed under hydrothermal conditions.

\section{Experimental}

\subsection{Hydrothermal treatment}

A ZSM-5 zeolite provided by INTEVEP, underwent hydrothermal treatment, according to the conditions of Table 1. The original zeolite without treatment was labeled as NHT.

The hydrothermal treatment consisted in the application of a constant air flow, dampened by the bubbling of boiling water, on a portion of NHT contained in a quartz reactor, within a tubular furnace (Figure 1), warmed up to 560, 760 and $960{ }^{\circ} \mathrm{C}$. After 120 minutes, the heating was suspended and dry air was injected into the reactor with the zeolite. The resulting three new zeolite samples were labeled HT560, HT760 and HT960, corresponding to the temperature of the hydrothermal treatment.

\subsection{Fourier transform infrared (FTIR) spectroscopy}

In order to study the $\mathrm{OH}$ groups on framework and extra-framework aluminum species, as well as their Brönsted and Lewis acidity, thin self-supporting wafers of each zeolite sample were prepared by the application of $207 \mathrm{MPa}$ of pressure on approximately $15 \mathrm{mg}$ of zeolite. The $1.3 \mathrm{~cm}$ diameter wafers were placed in a container that was inserted into a high-temperature vacuum cell (Figure 2). In each trial, the cell containing the sample was subjected to a pressure of $1.33 \mathrm{mPa}$ with a heating ramp rate of $10^{\circ} \mathrm{C} / \mathrm{min}$, until reaching the $500{ }^{\circ} \mathrm{C}$ for one hour. Afterwards, the sample was left to cool down to room temperature, to obtain a FTIR spectrum of the wafer surface without adsorbate. Then pyridine was added, with pressure increment of $133 \mathrm{~Pa}$, until reaching the saturation at approximately $667 \mathrm{~Pa}$. The gas in excess was removed by vacuum suction, until returning to the original pressure of $1.33 \mathrm{mPa}$. Having done this, it was proceeded to obtain FTIR spectra of each wafer, between 100 and $500{ }^{\circ} \mathrm{C}$, with intervals of $100{ }^{\circ} \mathrm{C}$. Spectra were recorded by a Perkin-Elmer FTIR System Spectrum GX instrument. Scan range: $400-5000 \mathrm{~cm}^{-1}$.

In order to study the structural order, dilution of the sample was required by preparing wafers of approximately $0.07 \mathrm{mg}$ of catalyst in $100 \mathrm{mg}$ of $\mathrm{KBr}$, under $103 \mathrm{MPa}$ of pressure. Spectra were recorded by a Perkin Elmer FTIR 1600. Scan range: $450-4400 \mathrm{~cm}^{-1}$.

Table 1. Experimental conditions for hydrothermal treatment.

\begin{tabular}{cc}
\hline Temperature & $560{ }^{\circ} \mathrm{C}, 760{ }^{\circ} \mathrm{C}$ and $960{ }^{\circ} \mathrm{C}$ \\
Rate of heating & $5{ }^{\circ} \mathrm{C} / \mathrm{min}$ \\
Air flow & $100 \mathrm{ml} / \mathrm{min}$ \\
Mass of the catalyst & $0.7-0.8 \mathrm{~g}$ \\
Time of treatment & $2 \mathrm{~h}$ \\
Water temperature & Boiling \\
Total pressure & Atmospheric \\
\hline
\end{tabular}

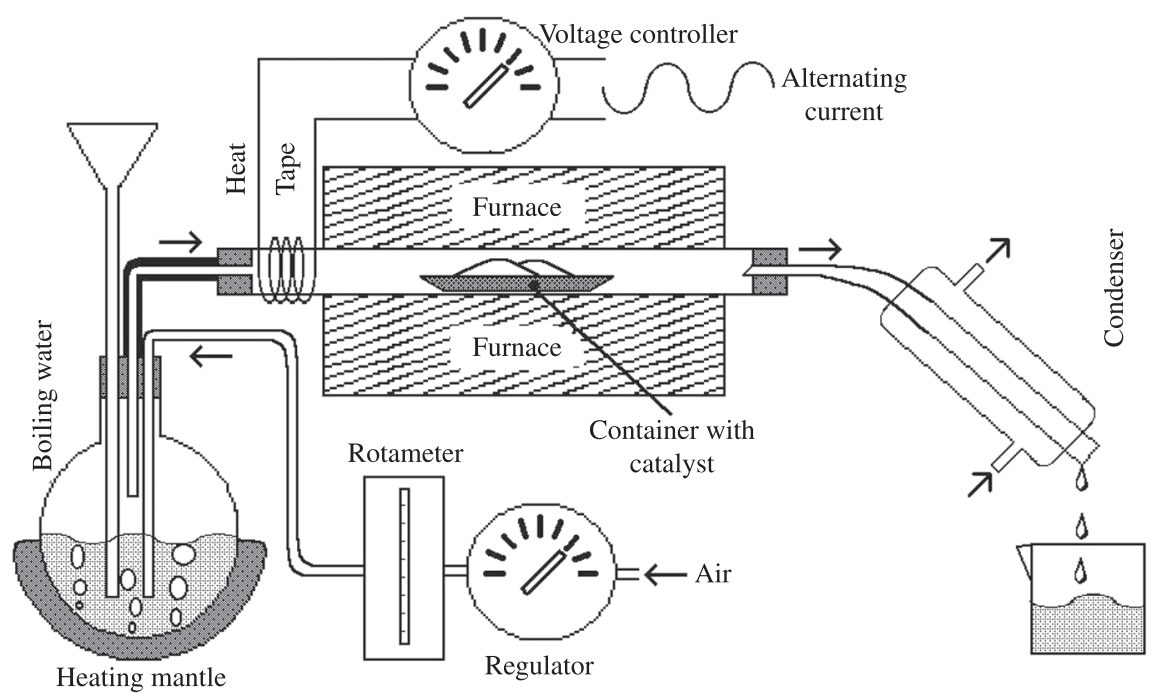

Figure 1. Schematic of apparatus for hydrothermal treatment. 


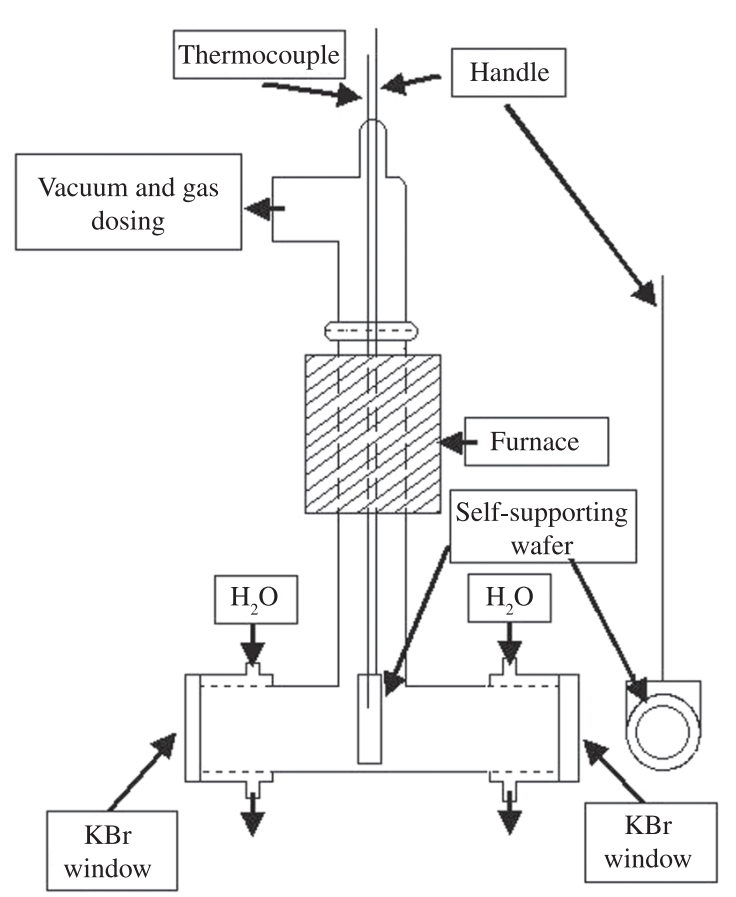

Figure 2. Schematic of high temperature vacuum cell.

\subsection{X-Ray diffraction}

The XRD study was performed using a Siemens D5005 diffractometer with a $\theta / \theta$ geometry in reflection mode, equipped with a graphite secondary monochromator, in the $2 \theta$ range of $5^{\circ}-60^{\circ}$ and a step size of $0.02^{\circ}$ and a time of 1.5 seconds. $\mathrm{Cu} \mathrm{K \alpha}(\lambda=1.54056 \AA)$ radiation, working at $40 \mathrm{Kv}$ and $30 \mathrm{~mA}$.

\subsection{Temperature-Programmed Desorption of Ammonia (TPD- $\left.\mathrm{NH}_{3}\right)$}

In order to obtain the TPD-NH $\mathrm{N}_{3}$ profiles, a Micromeritics TPD/TPR 2900 system equipped with a thermal conductivity detector (TCD) and its own software, was used. Each one of the samples (150 mg) was previously pulverized in an agate mortar and activated in a quartz reactor at $500{ }^{\circ} \mathrm{C}$, under a $50 \mathrm{~mL} / \mathrm{min}$ flow of dry air at $101 \mathrm{kPa}$ for one hour. Soon the samples were saturated with $\mathrm{NH}_{3}(50 \mathrm{~mL} / \mathrm{min}$ and $101 \mathrm{kPa}$ ) at room temperature for 15 minutes. Excess $\mathrm{NH}_{3}$ was eliminated with a $50 \mathrm{~mL} / \mathrm{min}$ helium flow $(207-276 \mathrm{kPa})$ for 15 minutes. The TPD experiments were performed with a continuous helium flow $(50 \mathrm{~mL} / \mathrm{min}, 207-276 \mathrm{kPa})$ and heating rate of $10^{\circ} \mathrm{C} / \mathrm{min}$ until $600^{\circ} \mathrm{C}$. This temperature was maintained for one hour afterwards.

\section{Results and Discussion}

\subsection{Behavior of the framework $\mathrm{OH}$}

Figure 3 shows a small variation of the signal around $3746 \mathrm{~cm}^{-1}$ of $\mathrm{O}-\mathrm{H}$ stretching vibrations of silanols before the addition of pyridine, with the increase of the steam temperature. This contrasts with the strong diminution

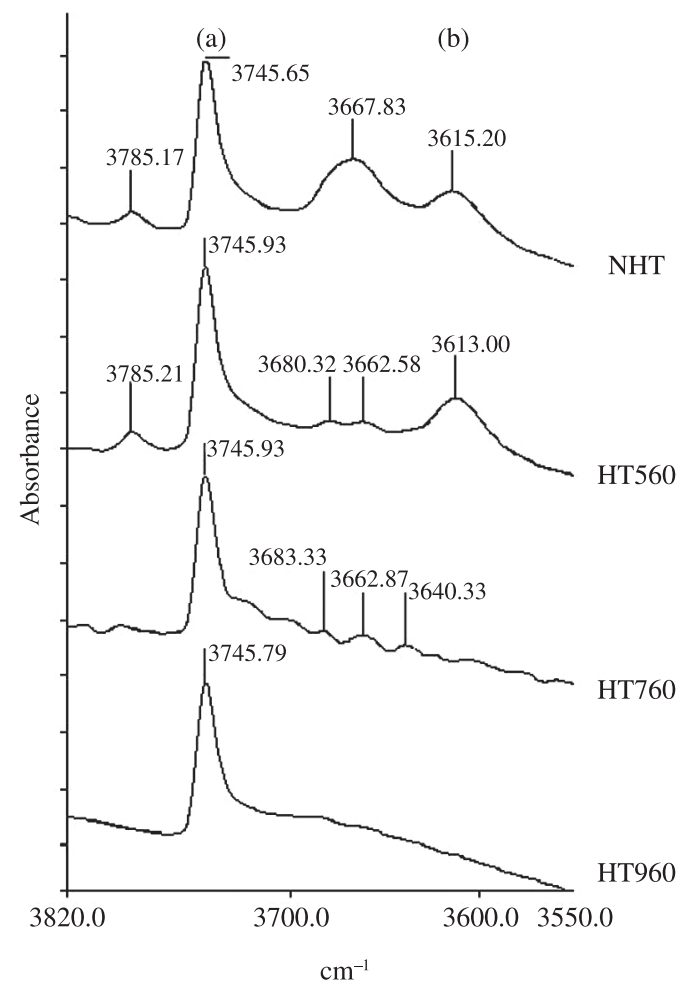

Figure 3. FTIR spectra of $\mathrm{O}-\mathrm{H}$ stretching vibrations in the region located between 3820 and $3550 \mathrm{~cm}^{-1}$ of the zeolite samples NHT, HT560, HT760 and HT960. a) Silanols (Si-OH) groups. b) Bridged Si-OH-Al groups.

of the signal at $3613-3617 \mathrm{~cm}^{-1}$ which is consistent with the reduction of the number of $\mathrm{Si}-\mathrm{OH}-\mathrm{Al}$ groups and the precipitation of aluminum outside the zeolite framework, after the hydrothermal treatment. The parent zeolite without hydrothermal treatment (NHT) also shows the presence of a weak band at $3785 \mathrm{~cm}^{-1}$ and a medium and broad band at $3700-3642 \mathrm{~cm}^{-1}$, that can be respectively assigned to $\mathrm{vOH}$ of terminal $\mathrm{Al}-\mathrm{OH}$ and $\mathrm{Al}-\mathrm{OH}$ still connected by one or two links to the crystal lattice ${ }^{34-36}$. At a first glance, the results don't support the latest presumption because fast disappearance of these bands, with the increase of the temperature of the hydrothermal treatment, does not agree with the increase of the presence of extra-framework aluminum species, resulting from hydrothermal treatment. A possible explanation for this behavior is the increasing condensation of the extra-framework aluminum hydroxyls to polymeric aluminum species. Such behavior was already been discussed in the literature ${ }^{1,12}$. Nevertheless, the difference of the spectra of the solids NHT, HT560 and HT760 minus HT960 (Figure 4) provides evidence of a small signal centered at $1622 \mathrm{~cm}^{-1}$ that agrees well with the deformation vibration of physically adsorbed molecular water ${ }^{37-40}$; whose intensity decreases with the increasing temperature of the hydrothermal treatment. Similarly, the bands at $3785 \mathrm{~cm}^{-1}$ and $3700-3642 \mathrm{~cm}^{-1}$, reasonably agree with the asymmetric and symmetric stretching vibrations of physisorbed water molecules ${ }^{32,33}$. This opens the possibility that the increase of the hydrophobic character, 
that accompanies the partial exit of tetrahedrally coordinated aluminum out of the crystalline network, by effect of the hydrothermal treatment, causes the diminution of the bands at 3785, 3700-3642 and $1622 \mathrm{~cm}^{-1}$. The presence of small amounts of water, after high-temperature treatment, should not be surprising: Milliken and coworkers ${ }^{41}$ found a persistent signal in the $2.7-3.0 \mu \mathrm{m}$ region that suggests the presence of structural $\mathrm{H}_{2} \mathrm{O}$ after heating several solids (including a zeolitic one) under vacuum at $700-850^{\circ} \mathrm{C}$. They appointed several possible causes, including water trapped in inclusions and/or its readsorption from the atmosphere. Moreover, Che and Glotch ${ }^{42}$ and Védrine ${ }^{43}$, have observed the presence of molecular water, even after pretreatment of solid samples to $500{ }^{\circ} \mathrm{C}$. These results support the possibility of an association between molecular water and extra-framework aluminum hydroxyls, as hydrated species whose disappearance results in the diminution of the last two mentioned bands. Similar observations were made in previous studies ${ }^{10,44}$.

The gradual disappearance of the signals at 3785 and $3700-3642 \mathrm{~cm}^{-1}$ (Figure 3) with the increase of the temperature during hydrothermal treatment, reveals small signals at $3640 \mathrm{~cm}^{-1}$ and $3683 \mathrm{~cm}^{-1}$ (zeolite sample HT760) that finally disappears in HT960. Most likely, the peak around $3640 \mathrm{~cm}^{-1}$ comes from $\mathrm{O}-\mathrm{H}$ stretching vibrations of silanols $(\mathrm{Si}-\mathrm{OH})$, hydrogen bonded with other silanols or water molecules, inside the zeolite channels ${ }^{45,46}$. Theoretical studies made by Jungsuttiwong and coworkers ${ }^{40}$, allowed assigning the signal at $3683 \mathrm{~cm}^{-1}$ to "free O-H" stretching vibrations, pertaining to $\mathrm{H}_{5} \mathrm{O}_{2}{ }^{+}$ions adsorbed inside the ZSM-5 zeolite channels.

The temperature at which desorption of pyridine occurs, with the consequent reappearance of to the $\mathrm{O}-\mathrm{H}$ stretching vibrations ${ }^{24}$ in the region located between 3700 and $3500 \mathrm{~cm}^{-1}$, indicates the strength of acid sites. Reappearance of the signal at $3613-3617 \mathrm{~cm}^{-1}$ (O-H stretching vibrations of $\mathrm{Si}-\mathrm{OH}-\mathrm{Al}$ ) in NHT could be observed, when pyridine was desorbed at 400 and $500^{\circ} \mathrm{C}$ (Figure 5). Nevertheless, the signal at

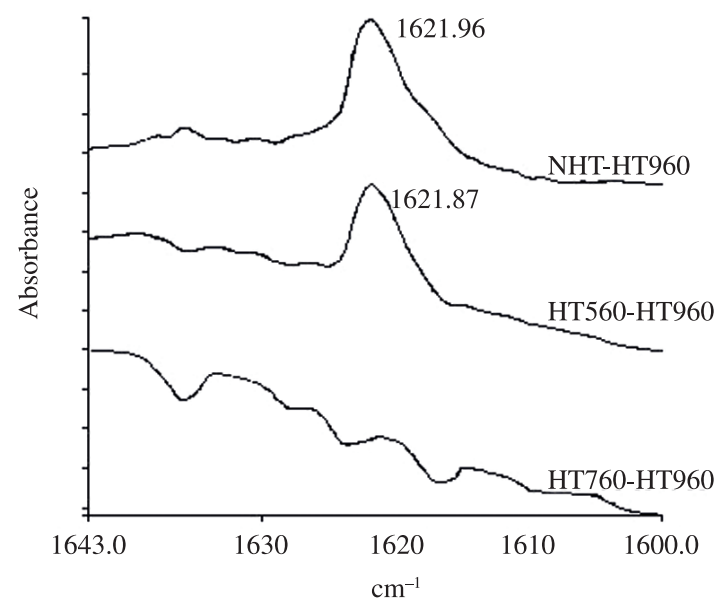

Figure 4. Difference spectra of the solids NHT, HT560 and HT760 minus HT960 in the FTIR region of the deformation vibration the adsorbed water.
$3700-3642 \mathrm{~cm}^{-1}$ did not show important changes. On the other hand, the absence of the band at $3785 \mathrm{~cm}^{-1}$, could be explained by the "irreversible" adsorption of pyridine on terminals extra-framework aluminum hydroxyls, with the consequent disappearance of its $\mathrm{vOH}$ vibration. This suggests that corresponding acid sites are stronger than the $\mathrm{Si}-\mathrm{OH}-\mathrm{Al}$ groups. That is incompatible with the position of the $\mathrm{vOH}$ signal at a higher frequency than the $\mathrm{vOH}$ signal of $\mathrm{OH}$ bridged groups. However, the removal of residual trapped water adsorbed on extra-framework aluminum by pyridine can be an alternative explanation for the absence of the band at $3785 \mathrm{~cm}^{-1}$. Guisnet and coworkers ${ }^{47}$ reported the irreversible disappearance of the same band under similar circumstances.

On the contrary, the band at $3700-3642 \mathrm{~cm}^{-1}$ may be the result of the superposition of the signals of symmetric stretching vibrations of physisorbed water molecules and Al-OH still connected by one or two links to the crystal lattice, where the latter is dominant. In this case, the removal of water adsorbed on extra-framework aluminum by pyridine, will not cause a noticeable effect on this signal.

In the FTIR spectra of zeolite sample HT560 (Figure 6), the signal at $3613-3617 \mathrm{~cm}^{-1}$ reappears after desorption of the pyridine at 400 and $500{ }^{\circ} \mathrm{C}$, while signals at 3785 and $3662 \mathrm{~cm}^{-1}$ (this last one being the remaining part of the 3700 $3640 \mathrm{~cm}^{-1}$, band) are absent. The growing condensation of the extra-framework aluminum hydroxyls to polymeric aluminum species, with the increase in the temperature of the

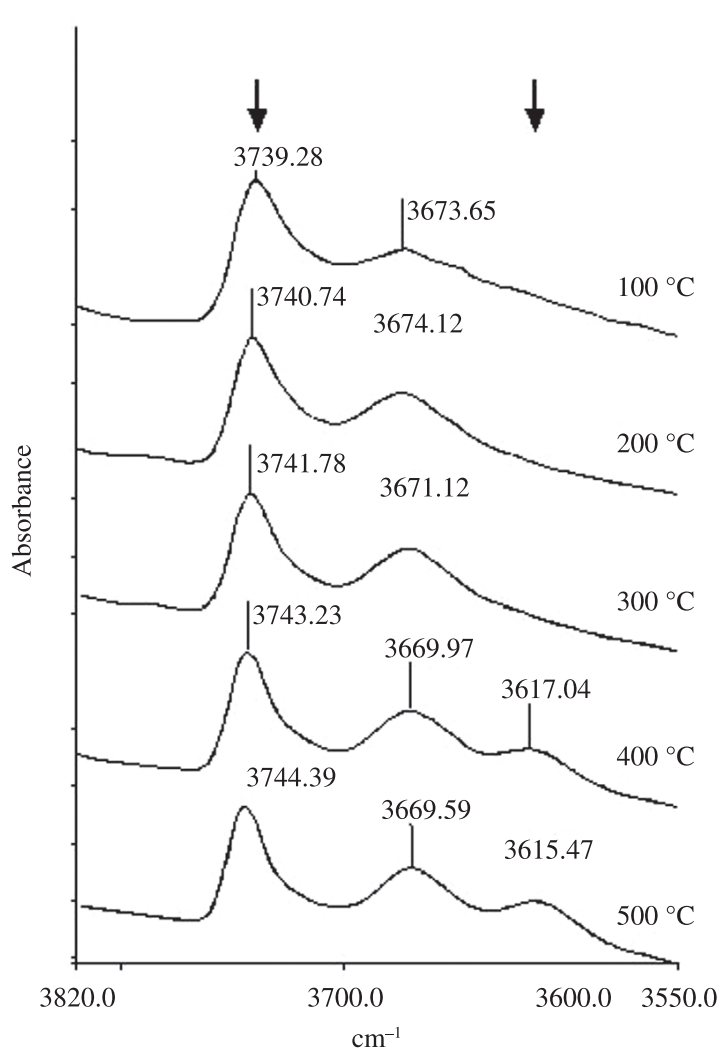

Figure 5. Reappearance of $\mathrm{O}-\mathrm{H}$ stretching vibrations bands, with the increase of pyridine desorption temperature of zeolite sample NHT. a) Silanols (Si-OH) groups. b) Bridged Si-OH-Al groups. 
hydrothermal treatment, diminishes its contribution to the signal at $3662 \mathrm{~cm}^{-1}$ promoting water as a main contributor of this signal. In this case, the removal of water adsorbed on extra-framework aluminum by pyridine, would cause the disappearance of signals at 3785 and $3662 \mathrm{~cm}^{-1}$.

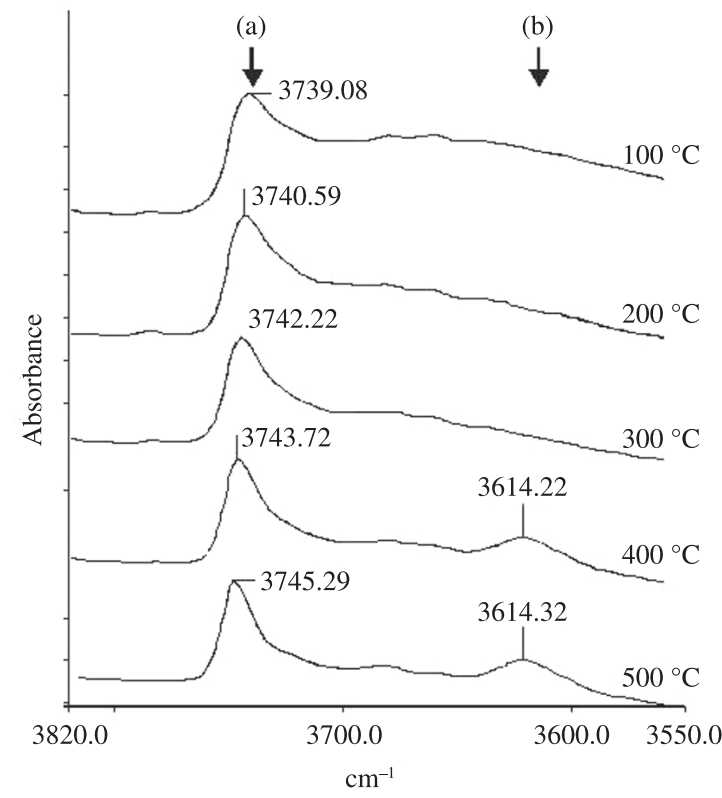

Figure 6. Reappearance of $\mathrm{O}-\mathrm{H}$ stretching vibrations bands, with the increase of pyridine desorption temperature of zeolite sample HT560. a) Silanols (Si-OH) groups. b) Bridged Si-OH-Al groups.
As expected, the presence of the signal at $3613-3617 \mathrm{~cm}^{-1}$ in FTIR spectra of HT760 and HT960 (Figure 7) was not observed, because it was not visible before the adsorption of pyridine (Figure 3 ). On the other hand, like in the other samples, the signal around $3746 \mathrm{~cm}^{-1}$ of $\mathrm{O}-\mathrm{H}$ stretching vibrations of silanols practically remained inalterable. Moreover, the reappearance of the bands at 3785, 3683, 3662 and $3640 \mathrm{~cm}^{-1}$ in the zeolite sample HT760 was not observed. Once again, the removal of water molecules by pyridine molecules seems to be the cause of the diminution of these signals below the sensitivity of the FTIR spectrometer.

\subsection{Brönsted and Lewis acidity}

FTIR spectroscopic study of pyridine adsorption at $\mathrm{T}_{\mathrm{s}}=200{ }^{\circ} \mathrm{C}$ (where $\mathrm{T}_{\mathrm{s}}$ is the temperature from which there is no overlap between the signals of the physisorbed and chemisorbed pyridine ${ }^{22,48-50}$ ) shows changes in the intensity of the bands between 1400 and $1570 \mathrm{~cm}^{-1}$ with the increase of the temperature of the hydrothermal treatment (Figure 8).

The variability, often caused by very subtle differences in the experimental conditions, between the reported values of the extinction coefficients $\epsilon_{\mathrm{B}}$ and $\epsilon_{\mathrm{L}}$, based on the absorbances of the bands around $1545 \mathrm{~cm}^{-1}$ (pyridinium ion bonded to a Brönsted site) and $1455 \mathrm{~cm}^{-1}$ (pyridine adsorbed on Lewis acid sites) led to use of the $\epsilon_{\mathrm{L}} / \epsilon_{\mathrm{B}}$ ratio (which is less sensible to changes in the experimental conditions). The $\mathrm{C}_{B} / \mathrm{C}_{\mathrm{L}}$ concentration ratio between Brönsted and Lewis acid sites was calculated through the equation: $\mathrm{C}_{\mathrm{B}} / \mathrm{C}_{\mathrm{L}}=\left(\in_{\mathrm{L}} / \epsilon_{\mathrm{B}}\right) .\left(\mathrm{A}_{\mathrm{B}} / \mathrm{A}_{\mathrm{L}}\right)$, where $\mathrm{A}_{\mathrm{B}} / \mathrm{A}_{\mathrm{L}}$ is the absorbance ratio between the bands around 1545 and $1455 \mathrm{~cm}^{-1}$. Under

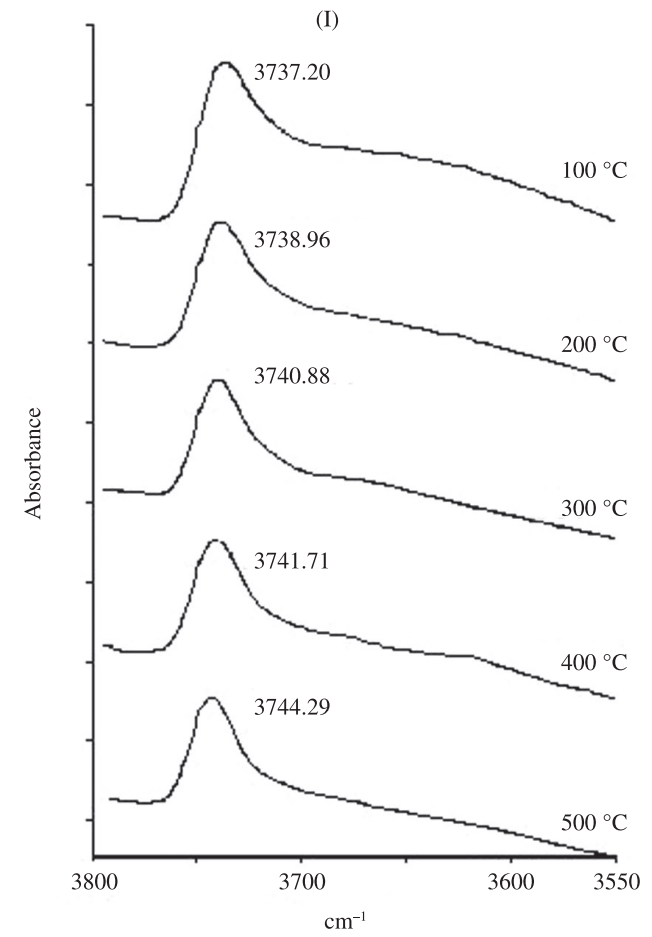

(II)

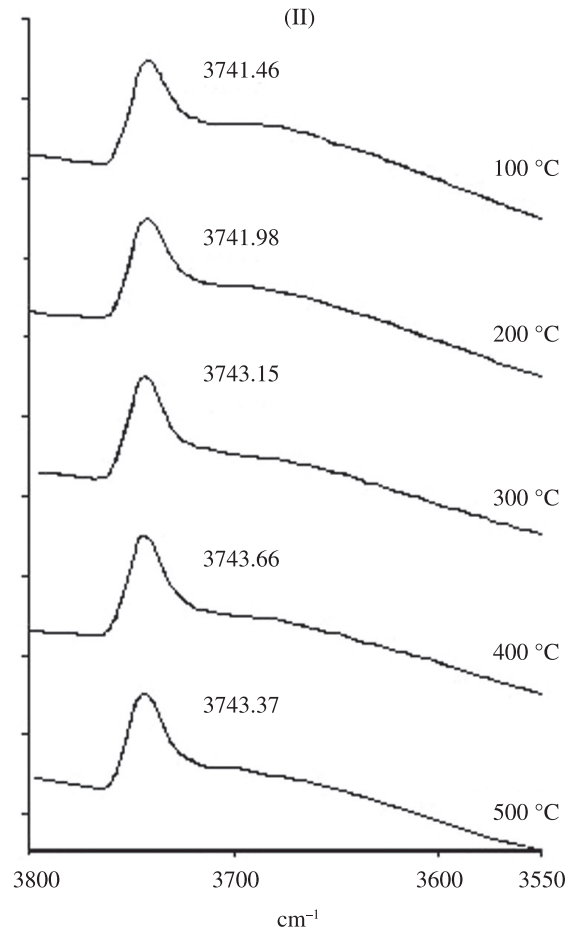

Figure 7. Behavior of FTIR spectra of the $\mathrm{OH}$-stretching region, with the increase of pyridine desorption temperature of zeolite samples I) HT760 and II) HT960. 
these considerations, the value of $\epsilon_{\mathrm{L}} / \epsilon_{\mathrm{B}}=0.7$, proposed by Robb and coworkers ${ }^{51}$, was used as the most adequate value for the determination of the $\mathrm{C}_{\mathrm{B}} / \mathrm{C}_{\mathrm{L}}$ ratio, in ZSM-5 catalysts with $\mathrm{Si} / \mathrm{Al}$ ratio superior to 7.5 .

The decrease of the $C_{B} / C_{L}$ ratio (Table 2) with the increasing temperature of the hydrothermal treatment can be explained by the transformation of tetrahedrally-coordinated framework aluminum in new species without Brönsted acidity. Another explanation for this behavior is the decreasing accessibility of pyridine molecules inside the zeolite channels (where it is presumed that the majority of the Brönsted acid-sites and a minor portion of the Lewis acid-sites are located) due to accumulation of extra-framework aluminum species.

The diminution of the intensity of the bands between 1400 and $1570 \mathrm{~cm}^{-1}$ (Figure 8) indicates that both Lewis and Brönsted acid site densities decrease at the same time. This contradicts the frequently accepted mechanism that underlies the increasing number of Lewis acid sites at the expense of the bridged $\mathrm{Si}-\mathrm{OH}-\mathrm{Al}$ sites $^{1-5}$, associated with Brönsted acidity, after hydrothermal treatment. This behavior may be attributed to the decreasing accessibility of pyridine molecules to Lewis acid sites inside the zeolite channels. However, the gradual conversion of the extra-framework aluminum hydroxyls (Lewis-associated) $)^{7-9}$ in polymeric species of low acidity ${ }^{1,12}$ may be another

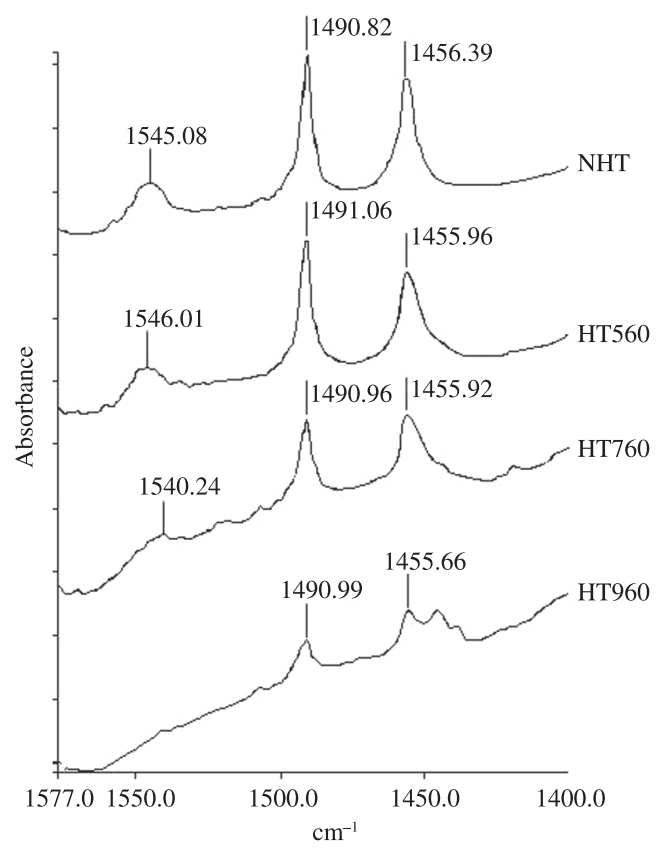

Figure 8. FTIR spectra of the adsorbed pyridine in the 1577-1400 $\mathrm{cm}^{-1}$ range after pyridine desorption at $200{ }^{\circ} \mathrm{C}$ of zeolite samples NHT, HT560, HT760 and HT960.

Table 2. Decrease of Brönsted to Lewis $C_{B} / C_{L}$ ratio with the increasing temperature of the hydrothermal treatment.

\begin{tabular}{cc}
\hline Zeolite samples & $\mathbf{C}_{\mathbf{B}} / \mathbf{C}_{\mathbf{L}}$ \\
\hline NHT & 0.384 \\
HT560 & 0.224 \\
HT760 & 0.116 \\
HT960 & 0.000 \\
\hline
\end{tabular}

possible cause. The results of TPD-NH $\mathrm{NH}_{3}$ analyses also seem to agree, when these show, at increasing hydrothermal treatment temperature, the decreasing of the profile areas of zones HT and LT, corresponding to higher and lesser than $300^{\circ} \mathrm{C}$ desorption temperatures from acid sites (Figure 9). Several authors ${ }^{52-56}$ consider that the peak in the LT zone results of $\mathrm{NH}_{3}$ desorption from non-acid sites. In order to verify or discard the last affirmation, the sample NHT was put under a superficial dealumination with $\mathrm{HCl} 1 \mathrm{~N}$. The elemental analysis (Table 3) shows that $\mathrm{HCl}$ treatment leads to an extraction of a $48 \%$ of total aluminum and $5 \%$ of total silicon. However, the comparison between TPD-NH profiles before and after treatment (Figure 10) shows that the

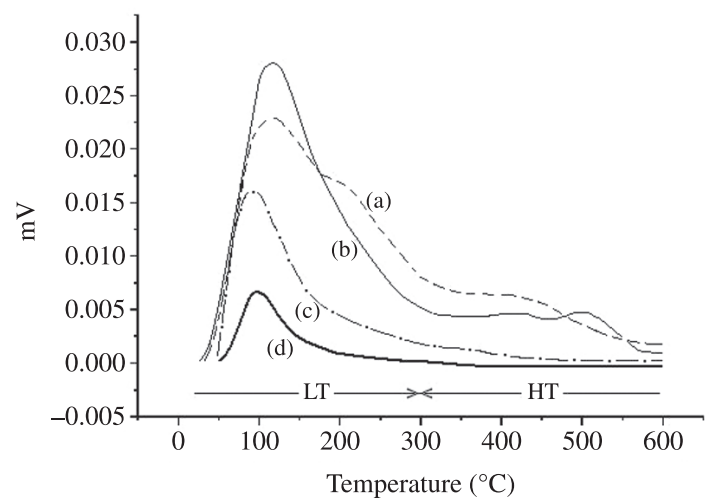

Figure 9. TPD- $\mathrm{NH}_{3}$ profiles of zeolite samples a) NHT, b) HT560, c) HT760 and d) HT960.

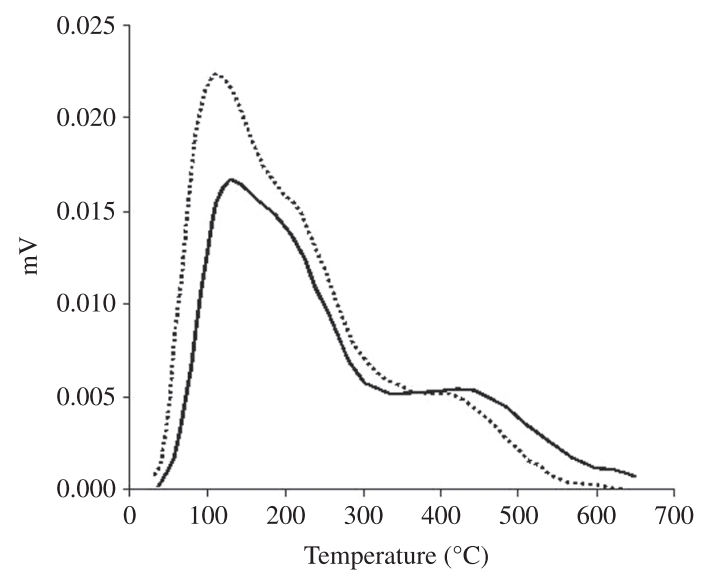

Figure 10. TPD-NH $\mathrm{N}_{3}$ profiles of zeolite sample NHT a) before and b) after treat with $\mathrm{HCl} 1 \mathrm{~N}$.

Table 3. Elemental analysis of zeolite NHT, before and after superficial treatment, with $\mathrm{HCl} 1 \mathrm{~N}$, using Inductively Coupled Plasma (ICP) techniques.

\begin{tabular}{ccc}
\hline Sample & \%Al & \% Si \\
\hline NHT (Before treatment) & $4.84^{\mathrm{a}}$ & $36.24^{\mathrm{a}}$ \\
NHT (After treatment) & $2.51^{\mathrm{a}}$ & $34.47^{\mathrm{a}}$ \\
Difference & $2.33^{\mathrm{a}}$ & $1.77^{\mathrm{a}}$ \\
\%Extracted & $48.13^{\mathrm{b}}$ & $4.88^{\mathrm{c}}$ \\
\hline
\end{tabular}

a: Relative to mass of sample; b: Relative to total aluminum; c: Relative to total silicon. 
HT area remains almost equal, whereas the LT diminishes significantly. This confirms the association between the LT peak and aluminum species of low acidity.

The temperature at which desorption starts and therefore, the disappearance of the bands of the adsorbed pyridine between 1400 and $1570 \mathrm{~cm}^{-1}$ begins, is an indicator of the force of the acid sites in the catalyst. In the zeolite

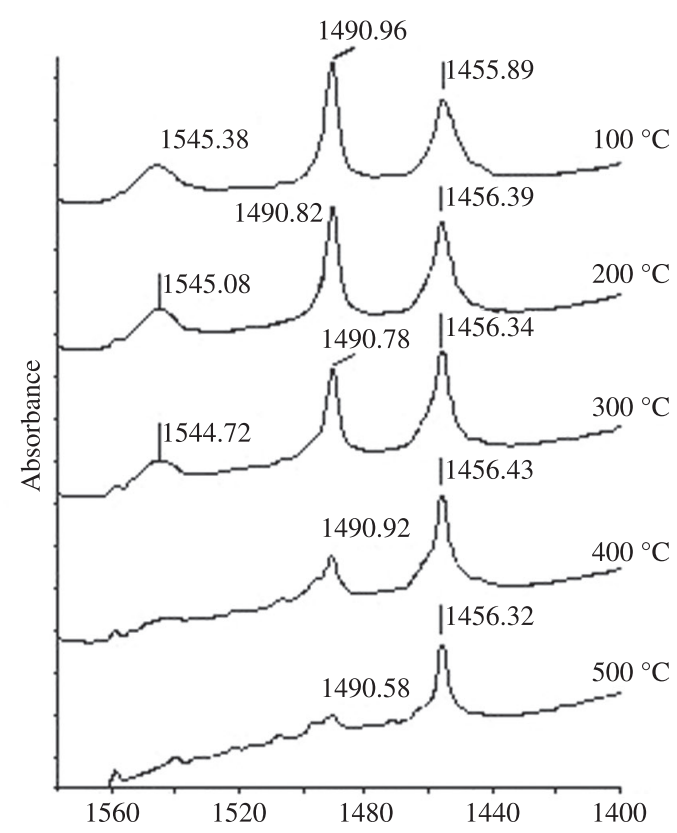

(a)

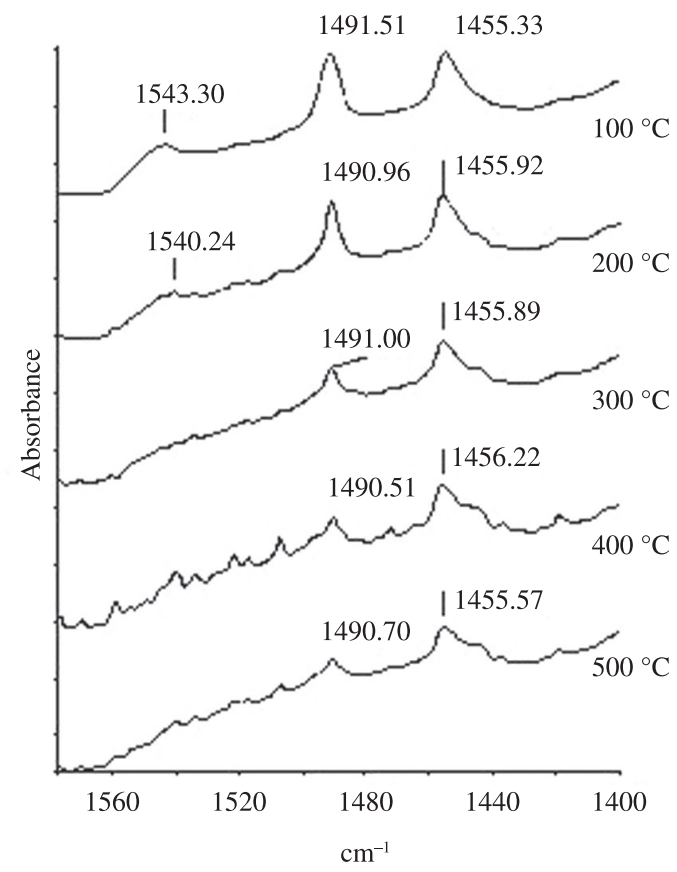

(c) samples NHT and HT560, the disappearance of the signal around $1545 \mathrm{~cm}^{-1}$ could be observed, when pyridine was desorbed at $400{ }^{\circ} \mathrm{C}$ (Figure 11, "a" and "b"). Nevertheless, the signal around $1455 \mathrm{~cm}^{-1}$ did not show important changes, although its intensity diminished slightly, with the increase of the desorption temperature. However, spectra of HT760 (Figure 11c) showed the disappearance of the signal around

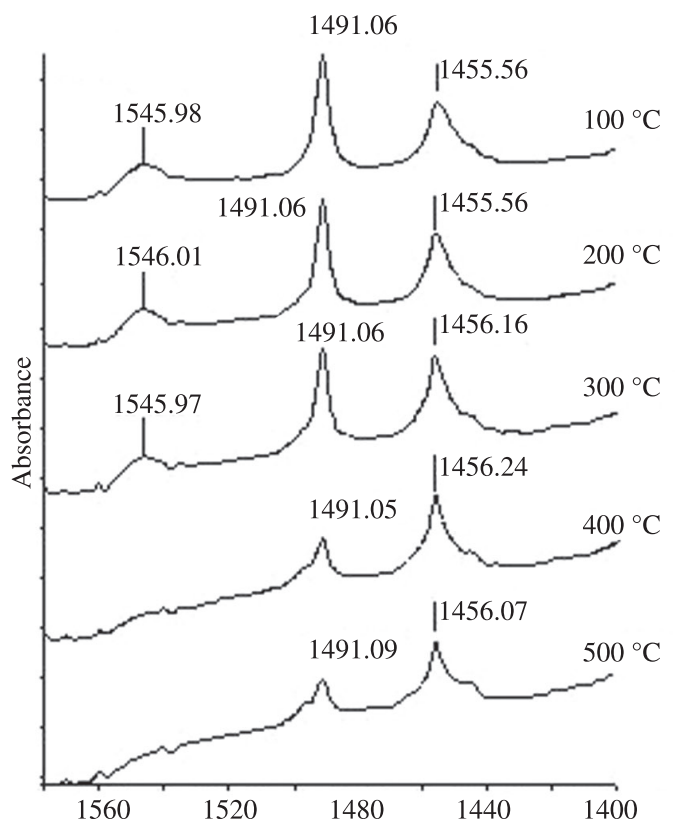

(b)

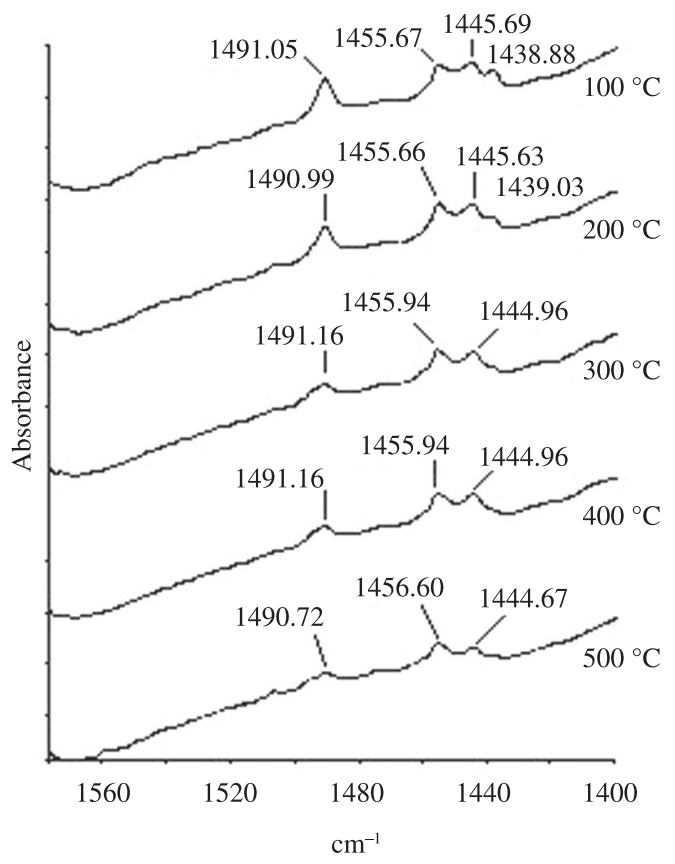

(d)

Figure 11. Behavior of the FTIR spectra between 1560 and $1400 \mathrm{~cm}^{-1}$, with the increase of pyridine desorption temperature of zeolite samples a) NHT, b) HT560, c) HT760 and d) HT960. 
$1545 \mathrm{~cm}^{-1}$ when the pyridine was desorbed between 300 and $500{ }^{\circ} \mathrm{C}$. The presence of this band at 100 and $200{ }^{\circ} \mathrm{C}$, contrasts with the apparent absence in this sample, of the band associated to the $\mathrm{Si}-\mathrm{OH}-\mathrm{Al}$ groups, at $3613-3617 \mathrm{~cm}^{-1}$ (Figure 7). Due to its low intensity, this last band can be below the resolution of the FTIR spectrometer. On the other hand, in the zeolite sample HT960 spectra, the signal around $1545 \mathrm{~cm}^{-1}$ is absent at all times (Figure 11d).

The non-disappearance of the band at $1455 \mathrm{~cm}^{-1}$, in the rank of studied temperatures of desorption, suggests that the Lewis acid sites are stronger than the pyridine accessible Brönsted sites.

At first glance, the results don't support the frequently accepted opinion that the Brönsted acid strength increases

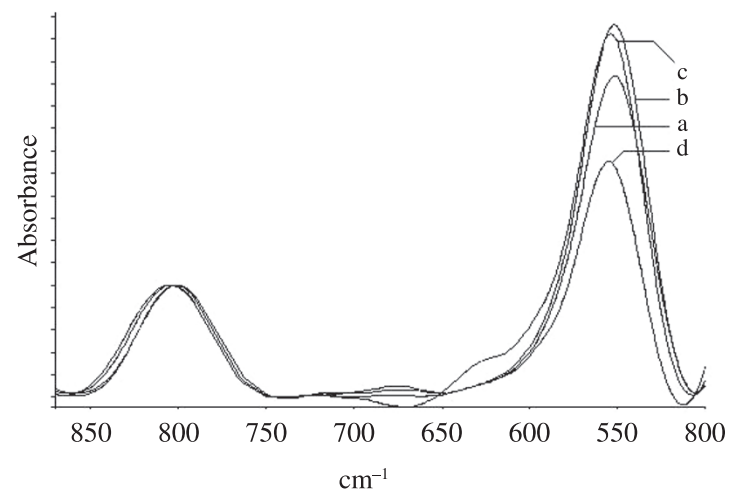

Figure 12. Superposition of FTIR spectra between 870 and $500 \mathrm{~cm}^{-1}$ in $\mathrm{KBr}$ pellets of zeolite samples a) NHT, b) HT560, c) HT760 and d) HT960.
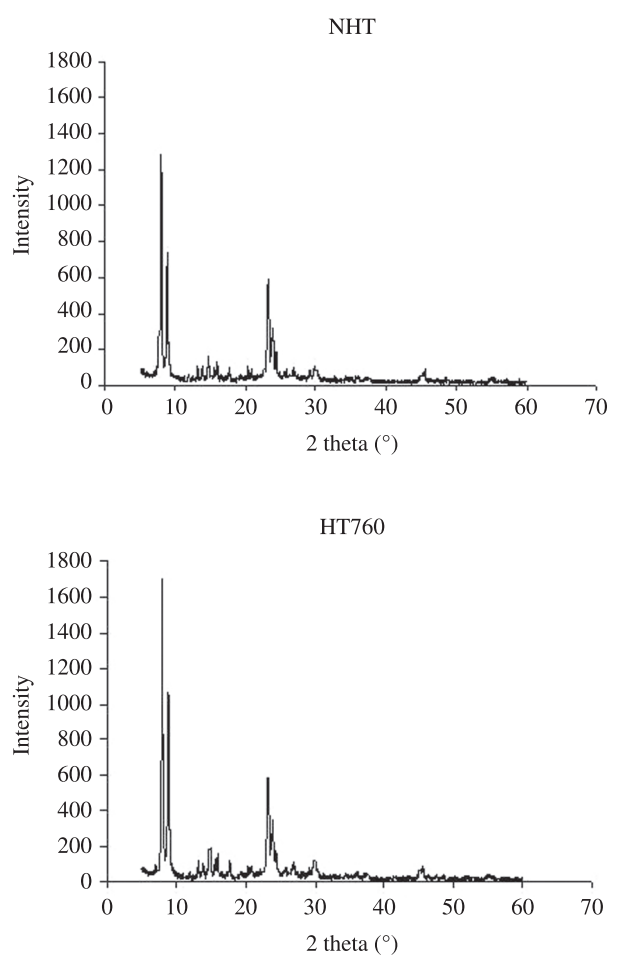

with the diminution of the acid-density ${ }^{57-59}$. Instead, the band at $1545 \mathrm{~cm}^{-1}$ disappears, in the solids NHT and HT560, at higher desorption temperatures than the solid HT760 (Figure 11), suggesting that Brönsted acid-sites with superior strength occur in samples with the highest densities of acid-sites. This behavior might be caused by the decreasing accessibility of pyridine molecules, due to accumulation of extra-framework aluminum species after the hydrothermal treatment, into the zeolite channels (where is presumed the presence of the strongest Brönsted acid sites) and/or the gradual transformation of tetrahedrally coordinated aluminum, associated with the strongest Brönsted acid sites, in extra-framework species of low acidity.

\subsection{Study of structural order}

Fourier transform infrared (FTIR) spectroscopy, of $\mathrm{KBr}$ pellets of zeolite samples NHT, HT560, HT760 and HT960, leads to very similar spectra. However, there are small differences in position and relative intensities of its bands (Figure 12).

The ratio between integrated absorbances of bands around 550 and $800 \mathrm{~cm}^{-1}$ (double five-member-ring and internal tetrahedra $\mathrm{TO}_{4}$ symmetric stretching vibrations, respectively) was used as a measure of crystallinity. The values of the ratio represented in Table 4, show a "volcano" behavior, characterized for an initial increase and subsequent decrease with increasing temperatures of hydrothermal treatment. Moreover, at the same table, the cristallinity, estimated from the peak height at $2 \theta=24.3^{\circ}$ of X-ray difractograms $^{31}$ (Figure 13), behave similarly. That suggests a previous step of structural realignment of zeolite sample at treatment temperatures less than $760{ }^{\circ} \mathrm{C}$.
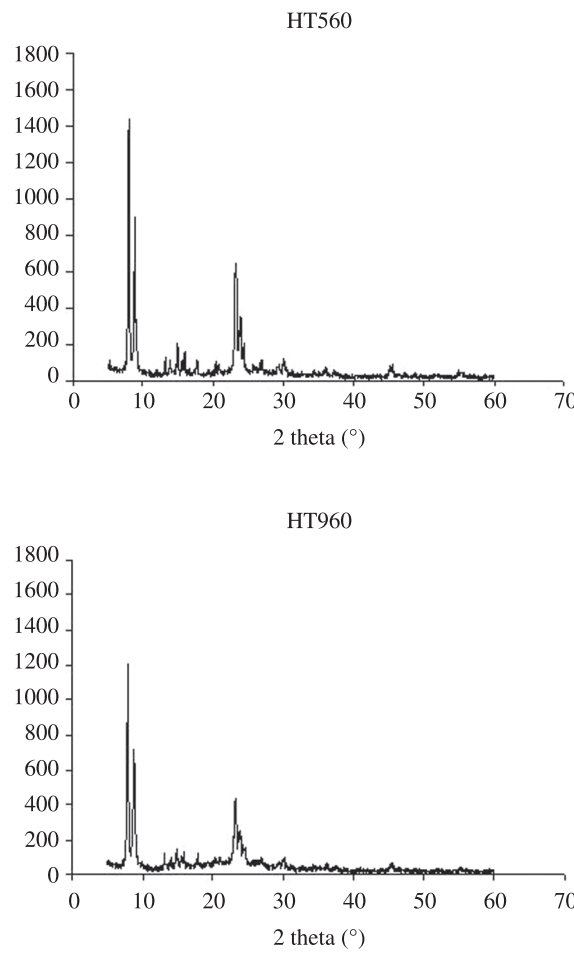

Figure 13. X-ray diffractograms of zeolite samples NHT, HT560, HT760 and HT960. 
Table 4. Relative crystallinity of zeolite samples NHT, HT560, HT760 and HT960. Calculated from the absorbance ratio (A/C) of bands at $550 \mathrm{~cm}^{-1}(\mathrm{~A})$ and $800 \mathrm{~cm}^{-1}(\mathrm{C})$ and from XRD peak height at a diffraction angle $2 \theta$ of $24.3^{\circ}$.

\begin{tabular}{cccc}
\hline Zeolite sample & A/C & \%A/C & \% Crystallinity. (DRX) \\
\hline NHT & 2.51 & 100 & 100 \\
HT560 & 2.93 & 117 & 115 \\
HT760 & 2.67 & 106 & 100 \\
HT960 & 1.63 & 65 & 71 \\
\hline
\end{tabular}

\section{Conclusions}

The results suggest an association between adsorbed molecular water and extra-framework aluminum hydroxyls generated after the hydrothermal treatment: The weak band at $3785 \mathrm{~cm}^{-1}$ can be assigned to asymmetric stretching vibrations of residual trapped water adsorbed on extra-framework aluminum. Likewise, a medium and broad band in 3700-3642 $\mathrm{cm}^{-1}$ can, probably, have its origin in the superposition of two $\mathrm{vOH}$ signals: from water (symmetric stretching vibrations) and non-terminals extra-framework aluminum hydroxyls (where the latter is dominant). In addition, the diminution in the intensity of these signals is consistent with an increase of the hydrophobicity and the gradual condensation of the extra-framework aluminum hydroxyls in polymeric species of weak acidity resulting from the hydrothermal treatment.

The gradual condensation of the extra-framework aluminum species to polymeric aluminum species of weak acidity, with the increasing temperature of the hydrothermal treatment, is the most probable cause of the diminution of the density of Lewis acid sites. On the other hand, decreasing accessibility of pyridine molecules to the strongest Brönsted acid sites into the zeolite channels due to the accumulation of extra-framework aluminum and/or the gradual transformation of these acid sites, into extra-framework species of low acid strength, may be the possible causes of the observed decrease in Brönsted acid site strength after the hydrothermal treatment.

Crystallinity shows a "volcano" behavior, characterized by an initial increase and subsequent decrease with increasing temperatures of hydrothermal treatment that suggests a previous step of structural realignment of zeolite sample at treatment temperatures less than $760^{\circ} \mathrm{C}$.

\section{Acknowledgments}

The author thanks the National Research Petroleum Institute of Venezuela (INTEVEP) and the Kinetic and Catalysis Laboratory of "Los Andes" University of Venezuela, for its invaluable support in providing source materials and characterization techniques for this work.

\section{References}

1. Zhang W, Han X, Liu X and Bao X. Characterization of the acid sites in dealuminated nanosized HZSM-5 zeolite with the probe molecule trimethylphosphine. Journal of Molecular Catalysis. A: Chemical. 2003; 194:107-113. http://dx.doi.org/10.1016/ S1381-1169(02)00466-1

2. Kiwi-Minsker L, Bulushev DA and Renken A. Active sites in HZSM-5 with low Fe content for the formation of surface oxygen by decomposing $\mathrm{N}_{2} \mathrm{O}$ : is every deposited oxygen active? Journal of Catalysis. 2003; 219:273-285. http://dx.doi. org/10.1016/S0021-9517(03)00222-7

3. Wichterlová B, TvarkováZ, Sobalík Z and Sarv P. Determination and properties of acid sites in H-ferrierite: A comparison of ferrierite and MFI structures. Microporous and Mesoporous Materials. 1998; 24:223-233. http://dx.doi.org/10.1016/ S1387-1811(98)00167-X

4. Borade R, Sayari A, Adnot A and Kaliaguine S. Characterization of acidity in ZSM-5 zeolites: an x-ray photoelectron and IR spectroscopy study. The Journal of Physical Chemistry. 1990; 94:5989-5994. http://dx.doi.org/10.1021/ j100378a068

5. Dapaah JKA, Andaluna L, Kobayashi T, Uemichi Y and Sugioka M. Enhancement of Catalytic Activity of Natural Zeolites by Surface Modeification for 1-Butene Isomerizatio. Muroran Institute of Technology. 1997; 47:89-95.

6. Mota CJA, Bhering DL and Rosenbach N. A DFT Study of the Acidity of Ultrastable Y Zeolite: Where Is the Brønsted/ Lewis Acid Synergism?. Angewandte Chemie International Edition. 2004; 4:30503052.

7. Nagy JB, Bodart P, Hannus I and Kiricsi I. Synthesis, characterization and use of zeolitic microporous materials. Szeged: DecaGen Ltd.; 1998.

8. Jacobs PA and Uytterhoeven JB. Assignment of the Hydroxyl Bands in the Infrared Spectra of Zeolites $X$ and $Y$. Heverlee: Centrum voor Oppervlaktescheikunde en Kolloïdale Schi-kunde, De croylaan 42, B-3030; 1972.

9. Covarrubias C, Quijada R and Rojas R. Ethylene polymerization using dealuminated ZSM-2 zeolite nanocrystals as an active metallocene catalyst support. Applied Catalysis. A: General. 2008; 347:223-233. http://dx.doi.org/10.1016/j. apcata.2008.06.023

10. Lisboa O, Sánchez M and Ruette F. Modeling extra framework aluminum (EFAL) formation in the zeolite ZSM-5 using parametric quantum and DFT methods. Journal of Molecular Catalysis. A: Chemical. 2008; 294:93-101. http://dx.doi. org/10.1016/j.molcata.2008.08.003

11. Yoon JW, Jhung SH, Choo DH, Lee SJ, Leed KY and Chang JS. Oligomerization of isobutene over dealuminated Y zeolite. Applied Catalysis. A: General. 2008; 337:7377. http://dx.doi. org/10.1016/j.apcata.2007.12.001

12. Kosslick H, Juan R, Fricke VA and Martin A. Study on the nature of aluminum in dealuminated zeolite ZSM-20. Studies in Surface Science and Catalysis. 1994; 84:1013-1020. http:// dx.doi.org/10.1016/S0167-2991(08)63636-8

13. Korobitsyna LL, Velichkina LM, Vosmerikov AV, Radomskaya VI, Astapova ES, Ryabova NV et al. Ultra-high-silica ZSM-5 zeolites: Synthesis and properties. Russian Journal of Inorganic Chemistry. 2008; 53(2):169173. 
14. Gonçalves ML, Dimitrov LD, Jordão MH, Wallau M and Urquieta-González EA. Synthesis of mesoporous ZSM-5 by crystallisation of aged gels in the presence of cetyltrimethylammonium cations. Catalysis Today. 2008; 133-135:69-79. http://dx.doi.org/10.1016/j. cattod.2007.12.108

15. Grigor'eva NG, Galyautdinova RR, Vosmerikov AV, Korobitsina LL, Kutepov BI and Dzhemilev UM. Conversion of a-Methylstyrene over Pentasil Zeolites with Various Silica Ratios. Petroleum Chemistry. 2008; 48:366-370. http://dx.doi. org/10.1134/S096554410805006X

16. Ding C, Wang X, Guo $X$ and Zhang S. Characterization and catalytic alkylation of hydrothermally dealuminated nanoscale ZSM-5 zeolite catalyst. Catalysis Communications. 2008; 9:487-493. http://dx.doi.org/10.1016/j. catcom.2007.07.013

17. Zhang Z, Liu D, Zhu X, Yu H, Liu S and Xu L. Acidity effects of $\mathrm{Hb}$ zeolite on olefin alkylation of thiophenic sulfur in gasoline. Journal of Natural Gas Chemistry. 2008; 17:45-50. http:// dx.doi.org/10.1016/S1003-9953(08)60024-9

18. Jin F, Cui Y and Li Y. Effect of alkaline and atom-planting treatment on the catalytic performance of ZSM-5 catalyst in pyridine and picolines synthesis. Applied Catalysis. A: General. 2008; 350:71-78. http://dx.doi.org/10.1016/j. apcata.2008.07.041

19. Benaliouche F, Boucheffa Y, Ayrault P, Mignard S and Magnoux P. NH3-TPD and FTIR spectroscopy of pyridine adsorption studies for characterization of Ag- and $\mathrm{Cu}$-exchanged X zeolites. Microporous and Mesoporous Materials. 2008; 111:80-88. http://dx.doi.org/10.1016/j.micromeso.2007.07.006

20. Moliner M, Díaz-Cabañas MJ, Fornés V, Martínez C and Corma A. Synthesis methodology, stability, acidity, and catalytic behavior of the member ring pores ITQ33 zeolite. Journal of Catalysis. 2008; 254:101-109. http://dx.doi.org/10.1016/j. jcat.2007.12.003

21. Bordiga S, Regli L, Cocina D, Lamberti C, Bjorgen M and Lillerud KP. Assessing the acidity of high silica chabazite H-SSZ-13 by FTIR using $\mathrm{CO}$ as molecular probe: Comparison with H-SAPO-34. The Journal of Physical Chemistry B. 2005; 109(7):2779-2784. http://dx.doi.org/10.1021/ jp045498w

22. Selli E and Forni L. Comparison between the surface acidity of solid catalysis determined by TPD and FTIR analysis of preadsorbed pyridine. Microporous and Mesoporous Materials. 1999; 31:129140. http://dx.doi.org/10.1016/ S1387-1811(99)00063-3

23. Emeis CA. Determination of Integrated Molar Extinction Coefficients for Infrared Absorption Bands of Pyridine Adsorbed on Solid Acid Catalysts. Journal of Catalysis. 1993; 141:347354. http://dx.doi.org/10.1006/ jcat.1993.1145

24. Van Bekkum H, Flanigen EM, Jacobs P and Jensen JC. Introduction To Zeolite Science and Practice. 2nd ed. New York: Elsevier; 2001.

25. Van Hoff JHC and Roelofsen JW. Chapter 7 Techniques of Zeolite Characterization. Studies in Surface Science and Catalysis. 1991; 58:241250. http://dx.doi.org/10.1016/S01672991(08)63605-8

26. Groen JC, Moulijn JA and Pérez-Ramírez J. Decoupling mesoporosity formation and acidity modification in ZSM-5 zeolites by sequential desilication-dealumination. Microporous and Mesoporous Materials. 2005; 87:153-161. http://dx.doi. org/10.1016/j.micromeso.2005.07.050
27. Park JN, Wang J, Hong SI and Lee CW. Effect of dealumination of zeolite catalysts on methylation of 2-methylnaphthalene in a high-pressure fixed-bed flow reactor. Applied Catalysis. A: General. 2005; 292:68-75. http://dx.doi.org/10.1016/j. apcata.2005.05.039

28. Beyer HK. Dealumination techniques for zeolites. Molecular Sieves. 2002; 3:204255. http://dx.doi.org/10.1007/3-54069750-0_3

29. Giannetto G, Montes A and Rodríguez G. Zeolitas. 2nd ed. Caracas: Innovación tecnológica; 2000.

30. Shukla DB and Pandya VP. Estimation of crystalline phase in ZSM-5 zeolites by infrared spectroscopy. Journal of Chemical Technology and Biotechnology. 1989; 44(2):147-154. http:// dx.doi.org/10.1002/jctb.280440206

31. American Society for Testing and Materials - ASTM D5758-01(2007)e1: Standard Test Method for Determination of Relative Crystallinity of Zeolite ZSM-5 by X-Ray Diffraction. ASTM; 2007.

32. Hair ML. Infrared spectroscopy in surface chemistry. New York: Marcel Dekker; 1967

33. Huang M, Adnol A and Kallaguine S. Silylation of H-ZSM-5: an X-ray photoelectron and infrared spectroscopy study. Journal of the Chemical Society, Faraday Transactions. 1993; 89(23):4231-4237. http://dx.doi. org/10.1039/ft9938904231

34. Trombetta M, Busca G, Storaro L, Lenarda M, Casagrande $\mathrm{M}$ and Zambon A. Surface acidity modifications induced by thermal treatments and acid leaching on microcrystalline H-BEA zeolite. AFT-IR, XRD and MAS-NMR study. Physical Chemistry Chemical Physics. 2000; 2:35293537. http://dx.doi. org/10.1039/b001916j

35. Roberge RM, Hausmann H and Holderich WF. Dealumination of zeolite beta by acid leaching: a new insight with two-dimensional multi-quantum and cross polarization 27Al MAS NMR. Physical Chemistry Chemical Physics. 2002; 4:3128-3135. http://dx.doi.org/10.1039/b110679c

36. Armaroli T, Bécue T and Gautier S. Diffuse Reflection Infrared Spectroscopy (DRIFTS): Application to the in situ Analysis of Catalysts. Revue de L'institut Français du Pétrole. 2004; 59(2):215237.

37. Kefirov D, Ivanova E, Hadjiivanov K, Dzwigaj S and Che M. FTIR Characterization of $\mathrm{Fe}^{3+}-\mathrm{OH}$ Groups in Fe-H-BEA Zeolite: Interaction with $\mathrm{CO}$ and NO. Catalysis Letters. 2008; 125:209-214. http://dx.doi.org/10.1007/s10562008-9577-3

38. Lasagabaster A, Abad MJ, Barral L and Ares A. FTIR study on the nature of water sorbed in polypropylene (PP)/ ethylene alcohol vinyl (EVOH) films. European Polymer Journal. 2006; 42:3121-3132. http://dx.doi.org/10.1016/j. eurpolymj.2006.03.029

39. Pavlović M, Baranović G and Lovrekovića D. Raman study of the bending band of water. Spectrochimica Acta Part A: Molecular Spectroscopy. 1991; 47(7):897-906. http://dx.doi. org/10.1016/0584-8539(91)80277-P

40. Jungsuttiwong S, Limtrakul J and Truong TN. Theoretical Study of Modes of Adsorption of Water Dimer on H-ZSM-5 and H-Faujasite Zeolites. The Journal of Physical Chemistry B. 2005; 109:13342-13351. http://dx.doi.org/10.1021/ jp045021k

41. Milliken RE and Mustard JF. Quantifying absolute water content of minerals using near-infrared reflectance spectroscopy. Journal of Geophysical Research. 2005; 110(E12). http:// dx.doi.org/10.1029/2005JE002534 
42. Che C and Glotch TD. The Infrared Spectra Study Of Dehydrated And Dehydroxylated Phyllosilicates. In: Prodeedings of the 40th Lunar and Planetary Science Conference; 2009; Woodlands, Texas. Woodlands; 2009.

43. Védrine JC, Auroux A, Bolis V, Dejaifve P, Naccache C, Wiezchowski $\mathrm{P}$ et al. Infrared Microcalorimetric, and Electron Spin Resonance Investigations of the Acidic Properties of the HZSM5 Zeolite. Journal of Catalysis. 1979; 59:248-262. http:// dx.doi.org/10.1016/S0021-9517(79)80029-9

44. Jiao J. Quantitative Characterization of Aluminum in Non-hydrated Zeolite Catalysts by Multi-nuclear Solid-state NMR Spectroscopy. Dr. rer. nat. [Thesis]. Universität Stuttgart zur Erlangung der Würde eines; 2006.

45. Fang $\mathrm{J}$ and Yongdan L. A FTIR and TPD examination of the distributive properties of acid sites on ZSM-5 zeolite with pyridine as a probe molecule. Catalysis Today. 2009; 145:101-107. http://dx.doi.org/10.1016/j. cattod.2008.06.007

46. De Aragão BJG and Messaddeq Y. Peak Separation by Derivative Spectroscopy Applied to FTIR Analysis of Hydrolized Silica. Journal of Braziliam Chemical Society 2008; 19(8):1582-1594. http://dx.doi.org/10.1590/S0103-50532008000800019

47. Guisnet M, Ayrault P, Coutanceau C, Alvarez MF and Datka J. Acid Properties of dealuminated bate zeolites by IR spectroscopy. Journal of the Chemical Society, Faraday Transactions. 1997; 93:1661-1665. http://dx.doi.org/10.1039/ a607609b

48. Selli E, Isernia A and Forni L. FTIR characterisation of Fe-silicalite catalysts for benzene oxidation to phenol by $\mathrm{N}_{2} \mathrm{O}$. Physical Chemistry Chemical Physics. 2000; 2:33013305. http://dx.doi.org/10.1039/b002334p

49. Morterra $\mathrm{C}$ and Cerrato G. Pyridine adsorption reveals high-coordinated cationic centres at the surface of microcrystalline ZnO. Catalysis Letters 1991; 10:357-364. http://dx.doi.org/10.1007/BF00769170

50. Rabeharitsara A, Cerqueira HS, Magnoux P, Guisnet M, Costa AF and Sousa-Aguiar EF. Transformation of methylcyclohexane on an FCC Catalyst. Brazilian Journal of Chemistry. 2003; 20(2):105110.

51. Robb GM, Zhang W and Smirniotis PG. Acidity of dealuminated bzeolites via coupled $\mathrm{NH}_{3}$ stepwise temperature programmed desorption (STPD) and FTIR spectroscopy. Microporous and Mesoporous Materials. 1998; 20:307316. http://dx.doi. org/10.1016/S1387-1811(97)00026-7

52. Lok BM, Marcus BK and Angell CL. Characterization of zeolite acidity. II. Measurement of zeolite acidity by ammonia temperature programmed desorption and FTIR spectroscopy techniques. Zeolites. 1986; 6(3):185-194. http://dx.doi. org/10.1016/0144-2449(86)90046-1

53. Zhao Q, Chen W-H, Huang S-J, Wu Y-C, Lee H-K and Liu S-B. Discernment and Quantification of Internal and External Acid Sites on Zeolites. The Journal of Physical Chemistry B. 2002; 106:4462-4469. http://dx.doi.org/10.1021/jp015574k

54. Rodríguez-González L, Rodríguez-Castellón E, Jiménez-López $A$ and Simon U. Correlation of TPD and impedance measurements on the desorption of $\mathrm{NH}_{3}$ from zeolite H-ZSM-5. Solid State Ionics. 2008; 179(35-36):1968-1973. http://dx.doi. org/10.1016/j.ssi.2008.06.007

55. Ma D, Zhang WP, Shu YY, Liu XM, Xu YD and Bao XH. MAS NMR, ESR and TPD studies of Mo/HZSM-5 catalysts: evidence for the migration of molybdenum species into the zeolitic channels. Catalysis Letters. 2000; 66(3):155-160. http://dx.doi.org/10.1023/A:1019099607029

56. Iwasaki M,Yamazaki K, Banno Kand Shinjoh H. Characterization

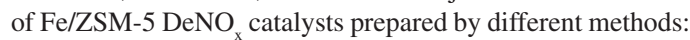
Relationships between active $\mathrm{Fe}$ sites and $\mathrm{NH}_{3}-\mathrm{SCR}$ performance. Journal of Catalysis. 2008; 260(2):205-216. http://dx.doi.org/10.1016/j.jcat.2008.10.009

57. Lu J, Zhao Z, Xu C, Duan A and Zhang P. Effects of Calcination Temperature on the Acidity and Catalytic Performances of HZSM-5 Zeolite Catalysts for the Catalytic Cracking of n-Butane. Journal of Natural Gas Chemistry. 2005; 14:213-220.

58. Dimitrova R and Popova M. Computer Simulation of the Beta Structure, with Different Lattice Ions and Reactivity, of Hydroperoxo-Metal Complexes Using an Embedded-Cluster Method. Molecular Engineering. 1999; 8(4):471-478. http:// dx.doi.org/10.1023/A:1008338026553

59. Cairon O and Chevreau T. Quantitative FTIR studies of hexagonal and cubic faujasites by pyridine and $\mathrm{CO}$ adsorption. Journal of the Chemical Society, Faraday Transactions. 1998; 94:323-330. http://dx.doi.org/10.1039/ a703444j 